${ }^{I}$ Universidade Federal do Pará (UFPA), Belém, PA;

e Universidade Federal do Oeste do Pará (Ufopa),

Instituto de Ciências da Sociedade, Santarém, PA, Brasil

lu_gcarvalho@yahoo.com.br

Luciana Gonçalves de Carvalho'

\title{
TRADIÇÕES DEVOTAS, LÚDICAS INOVAÇÕES: O SAIRÉ EM MÚLTIPLAS VERSÕES
}

\section{PONTO DE PARTIDA}

Estas notas e reflexões resultam de investigações realizadas no Inventário de Referências Culturais do Sairé (INRC-Sairé), entre 2012 e 20I4, e que vêm sendo continuadas e aprofundadas no âmbito de uma pesquisa mais ampla sobre as festas de santo e os processos de organização de comunidades no Baixo Amazonas. O INRC-Sairé teve como objeto a festa do Sairé de Alter do Chão, um distrito do município de Santarém/PA situado às margens do rio Tapajós.

Alter do Chão fica a $34 \mathrm{~km}$ da sede municipal de Santarém. Embora ainda guarde características de uma vila interiorana, trata-se de uma localidade em franca expansão, onde a especulação imobiliária tem promovido severa reconfiguração socioespacial, com a fixação de migrantes de classes média e alta no centro e no entorno da vila (área mais urbanizada e provida por serviços) e a realocação de moradores originários em novos bairros que vão se formando na periferia. A localidade tem praias de água límpida e areia clara, motivo pelo qual é muito procurada por moradores de Santarém e turistas de várias partes da região e do mundo. A economia local, portanto, é altamente dependente do turismo, e as atividades de roça, caça e pesca, que eram tradicionais até a década de I970, decaíram bastante.

O lago Verde, a ilha do Amor e a praça Sete de Setembro, com a Igreja de Nossa Senhora da Saúde, fundada em I722, integram a paisagem mais conheci- 
da de Alter do Chão e também constituem o espaço privilegiado de sociabilidade e confluência de moradores e de visitantes. Essa praça costumava abrigar os festejos do Sairé e outras festividades locais, mas perdeu essa serventia após a construção da praça do Sairé, em fins da década de I990. Com uma área muito maior, a nova praça também foi dotada de melhor infraestrutura para eventos do porte que o Sairé assumiu nos últimos anos (ver Foto I na pag. 238).

As festas de santo são celebrações tradicionais e populares ainda hoje usuais na Amazônia, e o Sairé é uma delas. Em linhas breves, essas festas atualizam um modelo festivo que valoriza, além dos ritos de natureza religiosa propriamente ditos, dimensões lúdicas do ato de celebrar em práticas de comensalidade, na entoação de ladainhas, em cortejos animados por folias (músicas em louvor aos santos, entoadas ao som do toque de caixas e outros instrumentos de percussão), em jogos e disputas festivas (Maués, I995; Figueiredo; Silva, I972; Costa, 20I I). Além disso, revelam um padrão de organização semelhante na constante presença de um barracão ou ramada - motivo pelo qual são também chamadas festas de ramada -, do(s) mastro(s) e todos os ritos que o(s) envolvem - busca, levantamento, derrubada -, e de personagens como juízes, mordomos, procuradores, donos ou cuidadores do santo, entre outros elementos.

O inventário do Sairé foi motivado pela solicitação de representantes de grupos responsáveis pela organização dessa festa, que nutriam a expectativa de obter seu registro como patrimônio cultural do Brasil. Inicialmente, eles almejavam não só o reconhecimento do valor cultural e patrimonial da celebração, mas também facilidades de acesso a recursos públicos e privados para sua realização anual. Entretanto, após a finalização das pesquisas e dos materiais dela decorrentes, a comunidade local não retomou, pelo menos por enquanto, a ideia inicial.

Destaque-se que a festa do Sairé é uma das mais antigas celebrações conhecidas na Amazônia e contabiliza pelo menos três séculos de existência. Há registros de comemorações do Sairé em diversos locais no Norte do Brasil, embora a festa só perdure em Alter do Chão, de tal forma que Nunes Pereira concluiu que "se [os dados] não nos autorizam a dar essa localidade como berço da ideia do Sahiré, amparam-nos, porém, ao afirmarmos que foi aquela antiga aldeia de índios a paisagem mais propícia a sua objetivação" (Pereira, I989: 69) (ver Foto 2 na pag. 239).

Festejos do Sairé desapareceram no Amapá, no Amazonas e em outras localidades do Pará (Boyer, 2008; Pereira, I 989; Rodrigues, 2009), e as circunstâncias históricas e socioculturais que levaram ao seu desaparecimento são insuficientemente conhecidas. Porém, uma série de indícios permite supor que as relações tensas e instáveis entre indígenas e missionários no processo colonizador, e entre devotos, párocos e outras autoridades no último século, contribuíram significativamente para que os festejos associados ao Sairé e outras expressões da religiosidade popular caíssem em desuso ou fossem silenciadas na Amazônia. 
A propósito, as relações essencialmente tensas com a Igreja, o Estado e a visão de mundo oficial estão na própria base das expressões da cultura popular, quer elas tenham motivação religiosa ou não. Assim apontaram Bakhtin (I993), Burke (I989), Chartier (I995), Davis (I990) e Revel (I989), em uma perspectiva histórica geral, e Galvão (I955), Braga (2007), Nogueira (2008) e Pacheco (2010), entre outros, sobre o contexto regional amazônico.

No que tange à festa do Sairé de Alter do Chão, especificamente, avento a hipótese de que as experiências históricas de embates entre festeiros (indígenas, caboclos e brancos), eclesiásticos e autoridades de governo foram apropriadas e positivadas pelos primeiros como estratégia de recriação e ressignificação da celebração, promovendo, por vias singulares, sua continuidade na localidade em questão. Ademais, creio que essas experiências se tornaram constitutivas da festa do Sairé como expressão objetificada da cultura de Alter do Chão, a ponto de ensejar ações de patrimonialização.

É provável que a própria continuidade histórica dessa festa se deva à sua capacidade de se transformar e amalgamar referências simbólicas heterogêneas. Ao longo dos séculos, ela atravessou muitas mudanças, entre as quais a sucessiva alternância da grafia do nome Sairé ou Çairé - uma polêmica que permanece até hoje - e uma sequência de alterações de data da celebração. Ainda, superou 30 anos de restrições imputadas pela Igreja Católica e voltou a ser praticada graças aos esforços da memória, da criatividade e da organização dos moradores de Alter do Chão. Em menos de três décadas, tornou-se o maior evento festivo e turístico do Baixo Amazonas paraense, incluindo em sua programação um festival protagonizado por duas agremiações de botos que se apresentam em uma espécie de arena de espetáculo, ao estilo dos bois-bumbás de Parintins.

Hoje, a festa do Sairé de Alter do Chão realiza-se em setembro, apresentando-se como uma celebração do Divino Espírito Santo que associa e articula, em múltiplos planos, ritos do catolicismo popular com formas tradicionais de expressão oral, musical e coreográfica, frequentemente designadas como folclóricas, mas também inspiradas em espetáculos de massa. Organizada em torno de dois espaços principais - o barracão e o Lago dos Botos - a festa é capaz de congregar públicos tão diferentes quanto modos distintos de celebrar.

Note-se, porém, que o Sairé nem sempre esteve associado ao Divino Espírito Santo. Nos registros mais antigos, a homenageada no ritual de Alter do Chão é Nossa Senhora da Saúde, padroeira da vila, e, em outras em localidades, são referidas execuções do Sairé como expressão de devoção a outros santos. Não estão claros o bastante os motivos e os modos pelos quais ele se associou à terceira pessoa da Santíssima Trindade, celebrada em inúmeras festas em diversas partes do Brasil e de Portugal (Abreu, I999; Ferretti, 2007; Leal, 2005, Gonçalves; Contins, 2008), mas é provável que essa associação tenha resultado dos processos de recriação da festa a partir de junho de 1973. 
TRADIÇÕES DEVOTAS, LÚDICAS INOVAÇÕES: O SAIRÉ EM MÚLTIPLAS VERSÕES

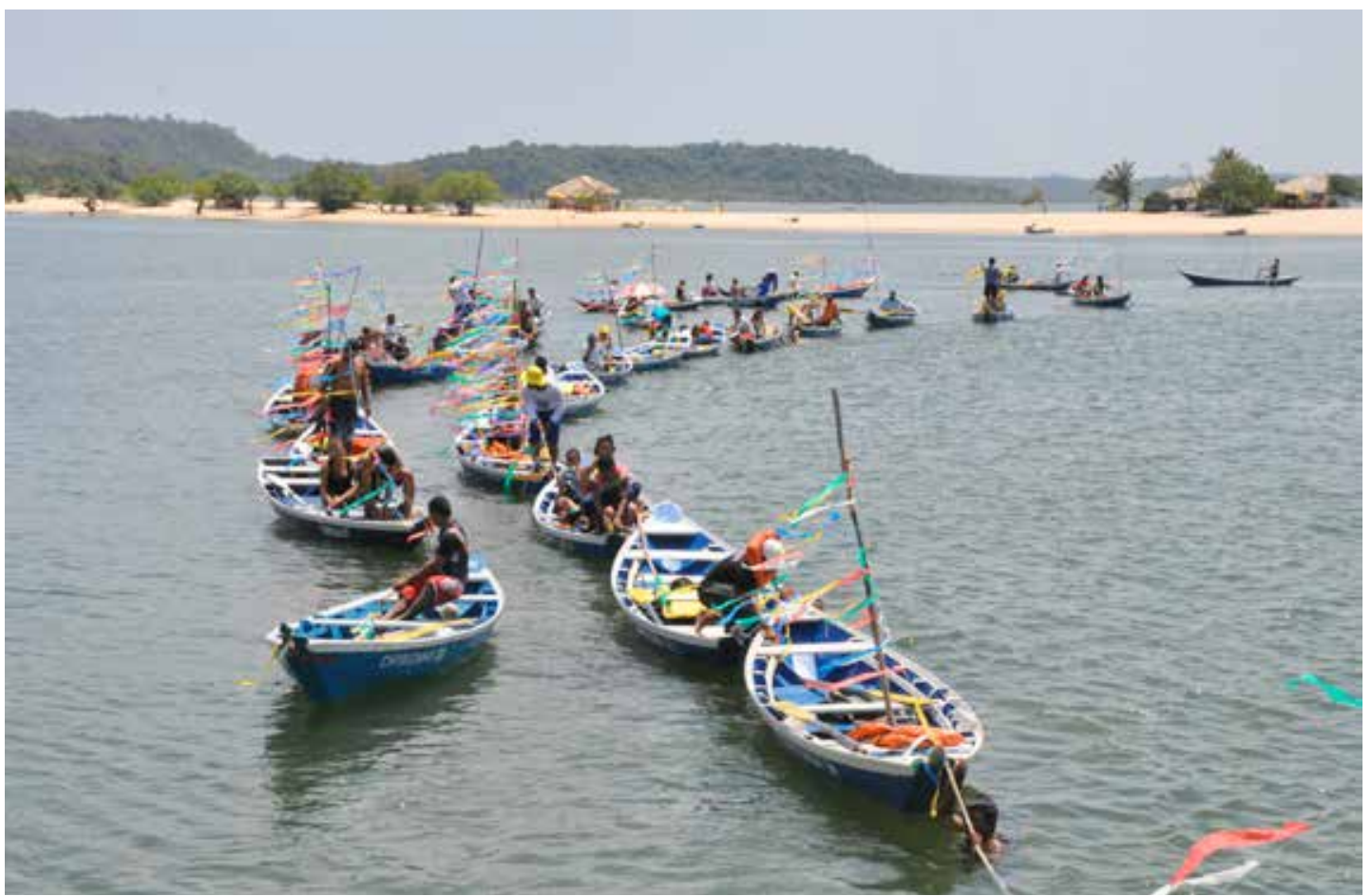

I

Busca dos mastros no lago Verde.

I3 set. 2012.

Coleção INRC-Sairé.

2

Matos, C.

Levantação do mastro.

I3 set. 2012.

Coleção INRC-Sairé. 


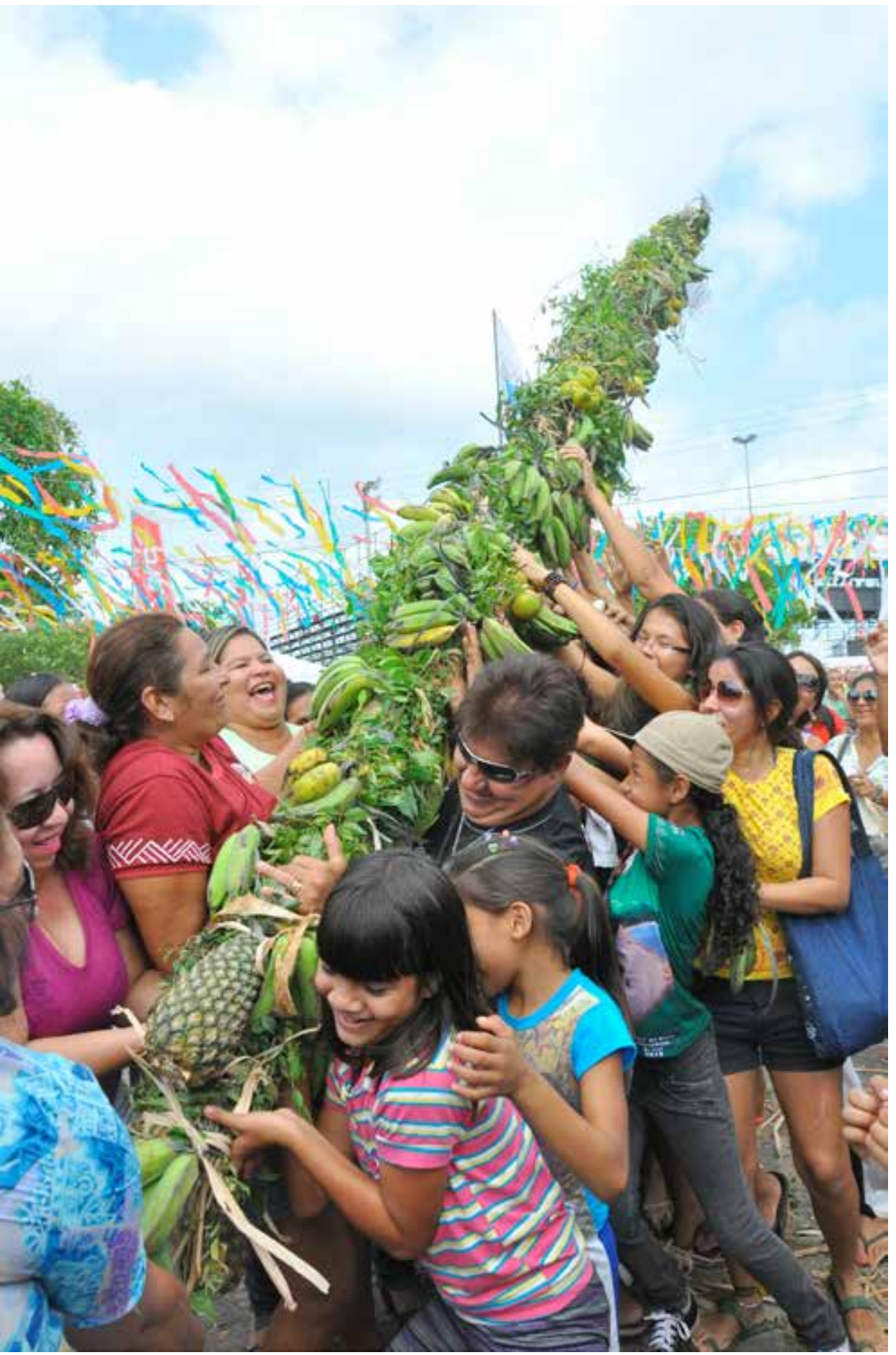




\section{O SAIRÉ CATEQUIZADO}

A festa do Sairé de Alter do Chão é objeto de diferentes narrativas fundacionais (Reis, I979). Em algumas, sua origem é interpretada como uma alegoria da chegada e fixação dos portugueses no rio Tapajós. Em outras, ela teria sido criada pelos jesuítas a fim de auxiliar na catequese dos indígenas. Ou, ainda, o ritual indígena encontrado na aldeia teria sido aproveitado pelos frades como mote para a catequização. Em comum, todas fazem referência às relações entre indígenas e missionários como o contexto das diferentes experiências constitutivas do Sairé: "Além da dança e do canto festivo, tem os tapuios no dia de alguma festa religiosa, como a de S. Tomé, S. João ou Santo Antônio, Santa Rita, um canto, antes uma saudação religiosa, introduzida n'estas festas pelos missionarios e chamada Sairé ou Turyua" (Rodrigues, I89o: 279).

Logo, seria o Sairé uma composição festiva mesclada de elementos católicos com ritos nativos, não necessariamente dotados de natureza religiosa. Dessa perspectiva, tão bem-sucedidos teriam sido seus amálgamas simbólicos, que Antônio Cândido considerou-o como o "caso mais interessante de festas e danças originadas no processo da catequese pelo encontro das duas culturas" (Cândido, s/d: 49).

O registro mais antigo da celebração do Sairé em Alter do Chão é atribuído ao missionário João Daniel (Pereira, I989), que esteve na Amazônia entre I74I e I757, e presenciou o Sairé na então Missão jesuítica de Nossa Senhora da Purificação.

Consiste o sairé em uma boa quantidade de meninos, todos em fileira atrás uns dos outros com as mãos nos ombros dos que lhe ficam adiante, em três, quatro ou mais fileiras; e na vanguarda anda um menino, se a dança é de ascânios, dos mais altos, ou menina, quando o sairé é de hembras, das mais taludas pegando com ambas as mãos nas bases de um meio arco, o qual em várias travessas está enfeitado com algodão, flores, e outras curiosidades (Daniel apud Braga, 2007: 65).

Assinale-se a importância das Missões religiosas na vida cultural dos povos nativos da Amazônia. Elas foram instaladas em várias localidades desde I659, quando o padre Antônio Vieira visitou a região e começou a enviar-lhe diversas incursões jesuíticas para catequização dos indígenas. As missões, de modo geral, e as jesuítas, em especial, operaram transformações profundas nas sociedades regionais, configurando um processo peculiar da colonização europeia. Segundo Prado Jr., "elas têm objetivos próprios: a propagação da fé, os interesses da Igreja ou das ordens respectivas, não importa; mas objetivos que, pelo menos nos métodos adotados pelos padres, forçados a isso pelas circunstâncias ou não, se afastam e até muitas vezes contradizem os objetivos da colonização leiga" (Prado Jr., I999: 9I).

As missões jesuíticas foram extintas no Pará em I759, sob as ordens do Marquês de Pombal. Mesmo assim, sua influência no Sairé foi notada por Bar- 
bosa Rodrigues mais de um século depois: "É o Çairé a última tradição do tempo das Missões dos Padres de Jesus" (Rodrigues, I890: 282).

Para o pesquisador e festeiro Edilberto Ferreira, natural de Alter do Chão, a ação jesuítica em relação à celebração foi "um ordenamento metódico de catequização dos aborígines, [...] uma forma fácil que encontraram os portugueses de converter aquele povo à sua religião e crença em seus deuses" (Ferreira, 2008: 68). Com efeito, diversos estudos argumentam que a liberalidade com que os jesuítas tratavam festas e rituais indígenas constituiu em uma estratégia poderosa na sua catequese e colonização.

A utilização da dança nas suas mais variadas formas foi adotada pelos jesuítas como um recurso pedagógico no exercício da catequese junto aos nativos. $\mathrm{O}$ uso desse recurso assim como do teatro, do canto e da música sempre fez parte dos ensinamentos da Companhia de Jesus, desde os primeiros contatos com os índios no Brasil. A estratégia era aproximar os ensinamentos cristãos às festas e rituais, o que na visão dos religiosos facilitaria o processo de aprendizagem dos preceitos religiosos e educativos (Dias, 2014: I4-I5).

No século XIX, fizeram registros do Sairé autores como: o major Alfredo Ladislau Baena, em I839; o geógrafo José Afonso de Moraes Torres e o oficial da Marinha Lourenço da Silva Araújo Amazonas, em I 852; o escritor Francisco Gomes de Amorim, em I856; o naturalista Henry Bates, em I863; o viajante Herbert Smith, em I879; e o escritor José Veríssimo, em I896. Desde então, a festa do Sairé de Alter do Chão tem sido estudada por pesquisadores de várias áreas de conhecimento.

Diversas pesquisas evidenciam que o próprio termo "sairé" é polissêmico, nomeando fatos de naturezas distintas e causando alguma confusão na compreensão do sentido em que o termo é usado em cada contexto. Çaerê, ou Salve! Tu o dizes, seria o significado da saudação Sairé, enunciada pelos nativos quando adentravam o círculo da dança ritual - uso que, segundo Ferreira (2008), foi abandonado ao longo do processo colonizador. Na prática, o termo designa a festa como um todo, a dança, a procissão ou o símbolo que nela é empunhado (Pereira, I989).

Esse símbolo, supostamente introduzido nos ritos pelos missionários, é um arco feito de cipó em forma de semicírculo, contando com três cruzes e enfeitado com fitas coloridas. Rodrigues interpretou-o como uma representação da Arca de Noé: "Este instrumento, inventado pelos missionários para perpetuar e firmar mais a religião entre os índios, tem uma significação bíblica. O çairé perpetua o dilúvio e as três pessoas da SS. Trindade" (Rodrigues, I890: 280) (ver Foto 3 na pag. 243)

Antigamente, o arco e os ritos do Sairé fizeram parte de diferentes festas de santo na região do Tapajós, como aquelas dedicadas a Nossa Senhora da Saúde (em Alter do Chão), Santo Antônio, São José e São Tomé. Assim atesta um registro de I762, feito pelo bispo da capitania do Pará, João de São José Queirós, em Vila Franca: 


\begin{abstract}
Veio uma dança de índias às portas das casas da residência em que estávamos, e ao seu modo dançaram muito honestamente, tendo cinco em fileira um semicírculo ou meio arco de pau; em que pegavam todas sustentando-o na base que do círculo inteiro seria o diâmetro, governando uma índia a dança, e sustentando com um listão preso ao mesmo arco, alargando-o ou recolhendo quando retrocediam ou quando ganhavam mais terreiro avançando com o dito arco, a que chamam sayré (Queirós apud Dias, 2014: I3).
\end{abstract}

Para Ferreira, a adoção do arco nos festejos de Alter do Chão consolidou a concepção da ideologia católica entre os nativos. Assim, por recomendação dos padres, a procissão do Sairé teria passado a levar à frente o arco, que os festeiros atualmente chamam de símbolo do Sairé ou, simplesmente, Sairé (Ferreira, 2008: 68).

\title{
O SAIRÉ PROIBIDO
}

Apesar das conexões íntimas entre elementos católicos e ritos indígenas no Sairé, as narrativas mais comuns dos moradores de Alter do Chão destacam no histórico da festa o evento da sua "proibição" pela Igreja em I943. A "proibição" do Sairé não é um fato isolado no contexto regional, visto que nos anos I940 a Igreja Católica estabeleceu limites rígidos de distância e silêncio em relação às festas de santo que ocorriam em todo o Pará. Em várias paróquias a população viu padres restringindo severamente expressões de religiosidade que já se haviam tornado tradicionais em comunidades rurais e urbanas do estado.

As festas de santo, conforme mostrou Galvão (I955), eram geridas pelos comunitários e tinham mínima presença eclesiástica. Ademais, estavam intimamente associadas ao consumo de bebidas, a cânticos, danças e outras práticas consideradas profanas pelas autoridades religiosas. Ao realizá-las, as comunidades subvertiam a ordem que a Igreja Católica tentava impor, e esta reagia, reclamando uma reforma moral.

O descontentamento dos párocos revelou-se em várias circulares expedidas pelo arcebispo Dom Antônio Lustosa, nos anos I930 e I940. Elas proibiam a realização de atos religiosos sem autorização prévia da autoridade eclesiástica e as celebrações conduzidas por leigos - que eram muito comuns nas localidades do interior, raramente visitadas pelos padres (Wagley, I977; Galvão, I955). As circulares também condenavam e pretendiam impedir as ladainhas, as esmolações - cortejos, normalmente animados por folias, que visavam à arrecadação de donativos para as festas de santo - e os arraiais, dentro e fora das igrejas (Leal, 20I4). Elas não tiveram o sucesso almejado pelo arcebispo, mas afetaram profundamente a dinâmica de comunidades que se preparavam, anualmente, para a festa do seu padroeiro ou santo de devoção (Rodrigues, 2009; Pacheco, 2010).

Em Alter do Chão, o Sairé foi afetado pela proibição de ritos festivos como a procissão organizada pelos moradores, que foi impedida de adentrar 


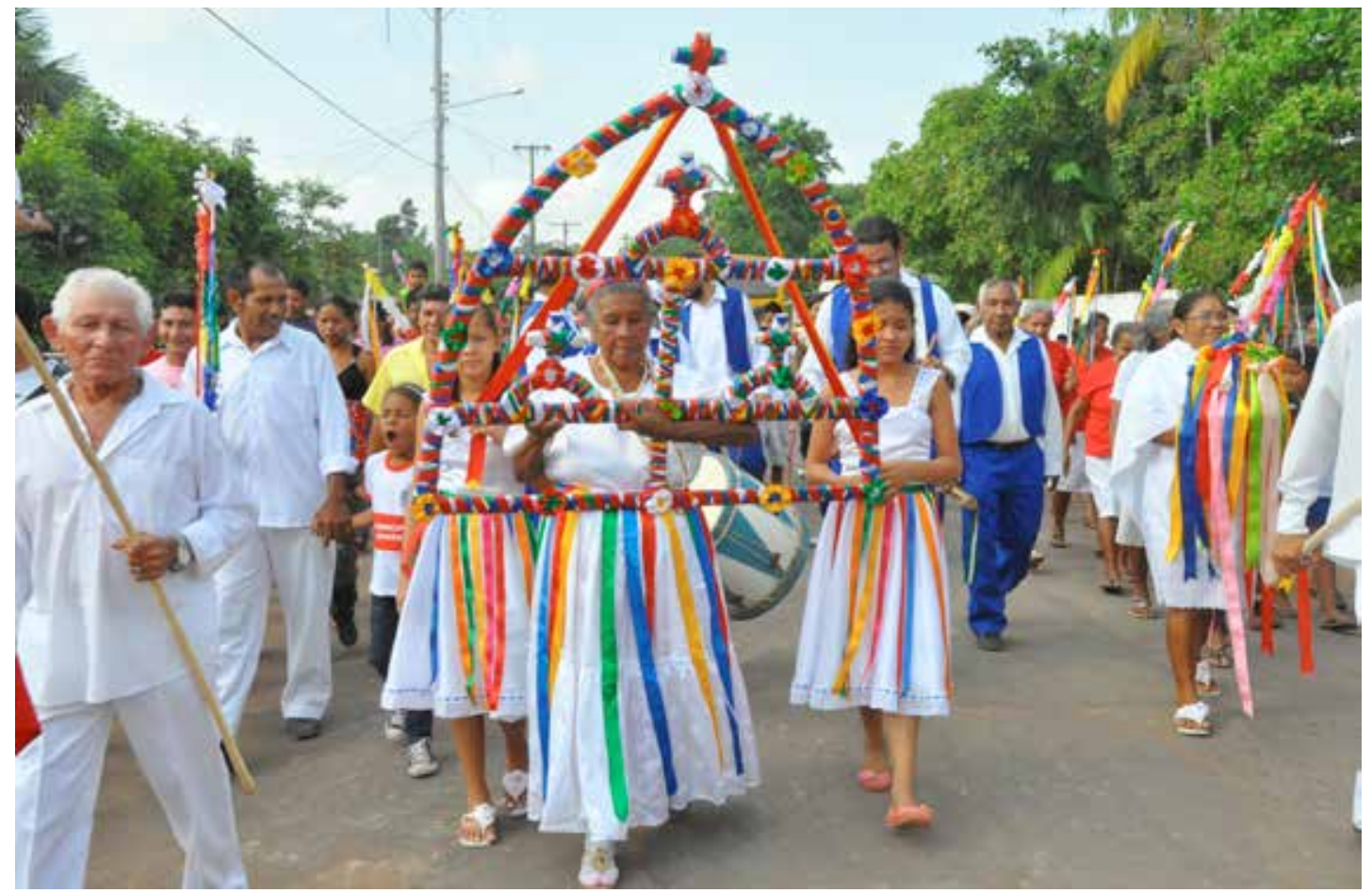

3

3

Matos, C.

Saraipora e moças-da-fita carregam o arco ou símbolo do Sairé na procissão de busca dos mastros.

I3 set. 2012 .

Coleção INRC-Sairé. 
a igreja. Segundo um antigo folião, I943 "foi o tempo que chegou os americanos e eles mataram a festa do Sairé... Eles interromperam a festa porque achavam que a festa... não pertencia à religião católica" (Ferreira, 2005: 60).

De acordo com Figueira (2013), em I940 a Prelazia de Santarém abrangia uma área de $600 \mathrm{mil} \mathrm{km²}$ e $\mathrm{s} 8$ paróquias, das quais apenas sete eram atendidas por padres residentes. Nesse contexto, padres americanos foram convocados para prestar serviços religiosos nas imediações do rio Tapajós. Em I943, chegaram à região quatro freis da Província do Sagrado Coração de Jesus, sediada em Saint Louis, nos Estados Unidos. Embora Alter do Chão fosse a sede da paróquia, como indica a autora, Belterra foi escolhida pelos americanos e se tornou o novo centro religioso da região.

Esse fato é bastante significativo para compreender a relevância da vila de Alter do Chão até I943; nessa época, as comunidades localizadas ao logo do rio Tapajós se deslocavam para a vila em tempo de festa. Seu Laudelino Sardinha traz a referência à atração que a festa do sairé exercia sobre as comunidades que circundavam o Tapajós: "Até I943 faziam junto a festa e várias pessoas acreditavam que o Sairé era Santo. A Igreja Católica em I943 proibiu a festa [...] A Igreja Católica não permitiu, porque já estava virando uma religião e o pessoal estava vindo de outras comunidades... pra participar da festa do Sairé e não da festa da Padroeira" (Figueira, 2013:6).

Para Nogueira, a procissão fora proibida "por força das desavenças que causava entre os seus participantes que, após as 'obrigações cristãs', esbaldavam-se em bebidas alcoólicas derivadas da mandioca ou da cana-de-açúcar" (Nogueira, 2008:I45). Decerto, o consumo do tarubá (bebida fermentada feita da mandioca, de teor alcoólico), julgado excessivo pelos religiosos, aliava-se à realização de danças e estimulava atitudes que aqueles viam como profanação. Na verdade, já no século XIX a Igreja procurava restringir a embriaguez no Sairé: "O espírito religioso [...] perpetua-se até hoje com fiel devoção e crença, mas já profanado pela civilisação, que introduziu n'elle a orgia, pelo que a autoridade ecclesiastica tem prohibido o seu uso. Servindo hoje para, pela oração, porem-se bem com Deus, é motivo para regalarem-se com as mulheres, no meio da embriaguez" (Rodrigues, I890: 280).

Por fim, Ferreira (2008) defende que, a "proibição da festa" se fazia também em repressão ao fato de que os donativos arrecadados pelos comunitários para a festa eram usados no barracão em prol do próprio povo que a organizava, e não destinados à Igreja.

Destaque-se que relatos de estudiosos e antigos moradores indicam que, enquanto perduraram as restrições ao Sairé em Alter do Chão, os devotos teriam continuado sua prática em outras localidades, especialmente em comunidades ribeirinhas do Tapajós onde não havia fiscalização por parte dos párocos. Nelas, podiam realizar cânticos, louvores, danças e procissões expulsas do centro da vila e da igreja. Desse modo, a "proibição" não teria significado de todo a suspensão dos ritos, mas, antes, impulsionado os devotos em direção a outras estratégias para sua realização. 
Infelizmente, muito pouco se sabe do período de I943 a I973, tanto em função da ausência de registros históricos, que praticamente cessaram durante a "proibição da festa", quanto em função do silêncio comumente adotado pelos festeiros e párocos a respeito do assunto. Como uma espécie de tabu, a "proibição" do Sairé em Alter do Chão tornou-se um tema evitado pelos sujeitos que a vivenciaram. Assim, esse evento tende a ser silenciado e, nas narrativas locais, a história do Sairé geralmente se divide em dois grandes momentos: antes de I943 e após I973, ano que marca o que designam como a "retomada da festa", um processo curioso e determinante da configuração contemporânea do evento.

\section{O SAIRÉ RETOMADO}

Antes de reiniciarem a festa, alguns moradores de Alter do Chão, animados com essa possibilidade, formaram um grupo e dividiram tarefas entre si. Segundo uma das líderes da turma, havia grande desejo de reviver os rituais de outrora, mas também a esperança de que a realização da festa contribuísse para o afluxo de turistas e a geração de renda na vila. Como a exploração da seringa entrara em declínio, restavam aos moradores a roça e a pesca artesanal, o que os deixava em precárias condições econômicas. Assim, a perspectiva de atrair mais visitantes lhes parecia promissora, como relatou um dos idealizadores da "retomada": "é que para as praias vinha pouca gente para prestigiar, não estava muito bom aqui, não tinha quase pessoas para vir aqui e nós decidimos fazer alguma coisa, levantar a vila, e a lembrança foi o Sairé" (Ferreira, 2005: 64).

O grupo da "retomada" saiu de casa em casa para recolher depoimentos dos mais idosos, a fim de reconstituir a celebração com auxílio dos fragmentos das memórias individuais. Sorteou entre casais da vila os cargos de personagens da festa, para que assumissem as respectivas responsabilidades. Promoveu bingos e vendas de comidas a fim de arrecadar dinheiro para a compra dos vários itens necessários à festa. Por fim, foi pedir ao pároco de Belterra autorização para realizá-la. Ele aquiesceu, com a ressalva de que ocorresse separadamente da festa de Nossa Senhora da Saúde. De acordo com um membro do grupo, "a igreja daqui era mandada pela igreja de Belterra, daí nós fomos falar com ele e ele disse que ia até ver como era esse negócio do Sairé, que podia fazer a primeira festa dia 20 a 24 de junho de I973" (Ferreira, 2005: 64).

A festa foi reintroduzida na vida da comunidade, celebrando o Divino Espírito Santo com ladainhas, folias (cânticos em homenagem aos santos, feitos ao som da percussão de taróis e outros instrumentos), procissões, bandeiras decoradas com uma pomba, coroa, mastros enfeitados com frutas e o mesmo arco em forma de semicírculo, ornado com três cruzes, que Barbosa Rodrigues comparou com a Arca de Noé. A esses elementos somaram-se expressões 
orais e musicais tradicionais da região, conferindo à festa um tom folclórico, segundo seus próprios organizadores.

O folclore, ele não tinha, nós criamos em cima da festa do Sairé, da semana de procissão da ladainha. A ladainha dele não tinha em especial pra ele [...] a gente rezava ou reza até agora a ladainha que é do Divino Espírito Santo, numa ladainha cantada em latim, por sinal muito bonita[...] e para incrementar mais a coisa nós criamos a ladainha em cima daquela procissão... (Ferreira apud Tenório, 201 2:28-29).

Dedicado à recriação das tradições do Sairé, o grupo da "retomada" acabou por promover mudanças significativas na estrutura da festa, agregando a ela um mosaico de expressões culturais que identificavam como parte do folclore da vila, e que não haviam sido referidas nas lembranças dos festejos anteriores à proibição. A respeito das inovações, o depoimento de um integrante daquele grupo é revelador:

Pra conseguir melhor nós fizemos estes cordões de brincadeira, de pássaros e se lembramos de várias danças que tinham aqui: o curimbó, do Pinduca é carimbó, o nosso aqui criado é curimbó, aí nós criamos uma valsa, a da ponta do lenço, e nós apresentamos até em Santarém. Essa valsa e o Cruzador Tupi, que é uma das maiores brincadeiras (Ferreira, 2005:66, grifo do autor).

Em relação às expressões culturais mencionadas, os moradores locais compartilhavam o mesmo sentimento de "perda" que Gonçalves identifica na retórica do discurso patrimonial: "Em suas narrativas, a perda pressupõe uma situação original ou primordial de integridade e continuidade, enquanto a história é concebida como um processo contínuo de destruição daquela situação" (Gonçalves, 2002: 87-88). Crendo que aquelas expressões iriam desaparecer, os organizadores introduziram-nas na festa. Como o Sairé não se realizaria junto às comemorações da padroeira e não se confundiria com os domínios da igreja, os párocos não se opuseram às inovações relativas ao folclore.

Porém, a demarcação de fronteiras entre os domínios dos festeiros e dos padres se traduziu materialmente no circuito adotado pela procissão, que marcou a separação nítida dos espaços da igreja e do barracão. A reconfiguração não eliminou a prática da promessa, os ritos de agradecimento e todas as experiências de fé e devoção que manifestavam a religiosidade popular na festa outrora proibida pela Igreja. Muito pelo contrário, essas experiências se restabeleceram fortemente no espaço físico e simbólico do barracão - só que associadas a práticas antes condenadas pelos padres como profanas. Assim, segundo o "grupo da retomada", o Sairé passou a ser "uma parte religiosa, porque ele ficou parecido com uma festa religiosa, então ele é uma coisa religiosa", mas também uma "coisa folclórica" - em comum acordo com os padres.

A igreja sabia porque participava com a gente do resgate do Sairé, muita gente que faz parte da igreja [...] só que eles, no primeiro ano, eles concordaram que o Sairé não fazia parte da igreja [...], foi aí que se criou o barracão e lá a gente fazia [...] As rezas era assistida da porta da igreja [...] então... não dizem que não é da 
religião, e que a procissão seja coisa folclórica, porque é. Então a gente resolveu tirar da igreja por completo e ficamos fazendo independente (Ferreira apud Tenório, 20I 2: 28-29, grifo do autor).

Por fim, a festa do Sairé de Alter do Chão "retomada" em I973 se configurou como um caso exemplar de (re)invenção de tradições, resultante de um processo que, apesar de inovar em certos aspectos, buscou estabelecer vínculos com um passado histórico que ficara interrompido em I943. Por definição, entende-se aqui como tradição inventada

um conjunto de práticas, normalmente reguladas por regras tácita ou abertamente aceitas; tais práticas, de natureza ritual ou simbólica, visam inculcar certos valores e normas de comportamento através da repetição, o que implica, automaticamente, uma continuidade em relação ao passado. Aliás, sempre que possível, tenta-se estabelecer continuidade com um passado histórico apropriado (Hobsbawn \& Ranger, I997: 9).

A festa do Sairé ficaria, a partir de então, sob a responsabilidade integral, inclusive financeira, das famílias organizadoras. Segundo um festeiro, "o povo foi aceitando assim, nós trabalhando, procurando recurso da nossa parte mesmo, fazendo farinha, bejú, vendendo frutas... Então os recursos não foi procurado nada de Santarém, nada, foi só aqui mesmo (Ferreira, 2005: 66, grifo do autor). Com o passar do tempo, os organizadores da festa buscaram apoio econômico de comerciantes e da Prefeitura de Santarém, que passou a financiar alguns itens, tornando especializadas determinadas atividades de organização da festa. Aos poucos, iniciou-se um processo de disputa pelo controle do evento, que assumiu conotações políticas e anunciou novas mudanças.

\section{O SAIRÉ REINVENTADO}

No fim dos anos I980 e início dos I990, a festa do Sairé enfrentava dificuldades econômicas, recebendo parcos incentivos do poder público. Os jovens também não se mostravam muito interessados nela, e os líderes da retomada, envelhecendo, não encontravam substitutos. Pesquisadores e moradores constatavam que a tradição tricentenária esmorecia diante da falta de motivação dos jovens e da ausência de uma política cultural que desse impulso à festa (Nogueira, 2008).

Foi nesse contexto que se formulou uma proposta voltada para a comercialização da festa, inovando-a, mas com a preocupação de preservar a suposta essência da sua "tradição". Assim, em I997, foram inseridas na programação da festa apresentações de grupos folclóricos que dramatizaram a lenda do boto. Com o sucesso da novidade, criou-se, em I999, o Festival dos Botos Tucuxi e Cor-de-Rosa, que adotou o modelo de disputa festiva do boi-bumbá de Parintins. Na sequência, artistas de visibilidade regional e nacional passaram a fazer shows no encerramento das noites de festa (Ferreira, 2008). 
Considero I997 um segundo marco da reinvenção das tradições locais, um divisor de águas para a festa e a comunidade de Alter do Chão. As inovações atraíram atenções políticas e contribuíram para a inserção da festa do Sairé em um calendário turístico para promoção em escala nacional. O vice-prefeito municipal de Santarém declarou, na época, que "até [19]96, o evento era inteiramente conduzido pelos moradores da vila. Foi então que resolvemos unir esforços para que a festa ficasse conhecida nacionalmente" (Leite, 200I: 99). Os grupos locais, em parceria com o Governo Municipal, implementaram medidas para divulgar a festa e atrair turistas, ao mesmo tempo que procuravam conciliar os desejos de mudança com os de preservação da tradição (Nogueira, 2008). Na interpretação de um pesquisador da comunidade, "na festa do 'Çairé' existe um modo relacional que é presente, está lá e nasce da aflição de não deixar morrer uma tradição. Os comunitários vivem a comunidade buscando um certo equilíbrio geral e a vontade de se renovar a cada dia" (Rêgo, 2003: 138).

Na prática, ocorreram investimentos na infraestrutura local para atender ao crescente mercado turístico e transferiu-se a festa, que era celebrada em junho desde I973, para julho, mês de férias. Como esse é um período de cheia dos rios, passou-se depois o evento para setembro, quando despontam o calor e as praias do Tapajós. Como estratégia de marketing, adotou-se a grafia "Çairé", reforçando a concepção local da origem e da identidade indígena e amazônica.

De acordo com Nogueira (2008), nos anos I 990 a Amazônia se tornou, ela própria, uma marca para a linguagem do mercado. As festas na floresta, segundo ele, surgiram como produtos culturais autenticamente amazônicos dotados do fetiche da mercadoria. O vice-prefeito de Santarém escreveu: "Na década de [I9]9o, a Amazônia fez ecoar um som que saiu da floresta e se estendeu pelo mundo afora. No ritmo das toadas de boi, músicas com balanço diferente (que não samba, pagode e axé music) surpreenderam o Brasil e, num segundo momento, conquistaram simpatia da Europa" (Leite, 200I: I I 2).

A festa reinventada demandou um espaço maior que o da Praça 7 de Setembro, onde ela era realizada, para comportar os participantes e seu novo público, principalmente nas apresentações dos botos. A nova praça do Sairé foi construída em uma área capaz de receber milhares de pessoas e passou a congregar o barracão, barraquinhas de comidas e bebidas, e um espaço próprio para o Festival dos Botos - uma espécie de arena circundada por arquibancadas e camarotes, acessíveis mediante pagamento ou cessão de ingresso pelos organizadores da festa.

A reorganização espacial da festa traduziu sentimentos e propostas ambivalentes de continuidade e ruptura com a tradição e a vida comunitária, que ficou mais restrita ao barracão e seu entorno, onde todos podem entrar, circular e participar livremente dos ritos. No plano simbólico, houve um reposicionamento dos universos festivos concebidos como sagrado ou profano.

A mudança demandou adaptações nas formas de composição e apresentação dos grupos organizadores da procissão, das músicas e das danças. Os 
grupos folclóricos locais adotaram indumentárias padronizadas para valorizar a visualidade nas apresentações para espectadores posicionados em arquibancadas. O novo espaço da festa acentuou a distinção entre festeiros, atores e espectadores. Desde então, é no Lago dos Botos que eles se apresentam nas noites de festa (ver Foto 4 na pag. 25I).

No mesmo local, os botos Tucuxi e Cor-de-Rosa exibem-se para jurados que, ao longo de duas horas, pontuam itens como: carimbó, cantador/apresentador, alegorias, rainha do Sairé, rainha do Lago Verde, curandeiro, tribo, evolução, menina do boto, cabocla borari, boto encantador, momento da sedução e galera/torcida organizada. A partir desse repertório comum e permanente, sua disputa festiva surpreende a cada ano, trazendo inovações em alegorias, fantasias, personagens e danças regionais.

Na primeira década de 2000 o Sairé de Alter do Chão ganhou espaço na mídia geral e especializada em turismo. A própria Igreja Católica, reconhecendo o valor cultural e a importância da festa para a comunidade, reaproximou-se dela, particularmente dos ritos do barracão. O pároco local em 2013, convencido da "mistura" de elementos ibéricos e indígenas que marca o "catolicismo popular, o catolicismo amazônico", resumiu em uma entrevista a nova perspectiva da Igreja:

Muita gente confundiu certos elementos que são de origem católica e têm uma procedência ibérica como se fossem indígenas, por exemplo, as bandeiras. As bandeiras, na verdade, estão presentes em todas as festas do Divino em todo o mundo [...]. O que é adorado, o que é venerado é a coroa do Divino... é a coroa que é venerada, que é beijada, ela que é o símbolo do Espírito Santo. Então o que nós vemos aqui hoje no Sairé é uma, para nós como igreja, é uma revitalização, ali na praça, de um culto ao Divino Espírito Santo, como outros cultos que estão aí. É um culto muito antigo, lá de Don Diniz e a Princesa Dona Izabel, Rainha Izabel de Portugal, que tinha uma devoção muito grande com o Divino Espírito Santo, tem toda essa história. [...] Essa tradição, isso que nós temos aqui, tem um elo para a Idade Média, um elo que vem da Itália que vai para toda a igreja na Europa, vai para Portugal e, de Portugal e vem para pras colônias (Padre José Cortes, 20I3).

A reaproximação teve início com pároco local, e, em 20 I I foi marcada pela presença do próprio bispo da diocese, que realizou a celebração de abertura da festa, dando ênfase à presença do Espírito Santo e ao sentimento de identidade dos comunitários com a tradição do Sairé. Depois, o padre da igreja de Nossa Senhora da Saúde se tornou responsável pelas celebrações de abertura e de encerramento da festa.

\section{SAIRÉ RESSIGNIFICADO}

A inegável capacidade de articular diferentes referências culturais num esforço constante de recriação consciente das tradições locais contribuiu, decerto, para a permanência histórica da festa do Sairé em Alter do Chão. Como se viu, 
as diversas formas de participação dos indivíduos na celebração desafiam as dicotomias comuns entre tradição e inovação cultural, ou entre sagrado e profano - muito embora esses adjetivos sejam usados pelos próprios festeiros para qualificar as atividades desenvolvidas dentro e no entorno do barracão, e no Lago dos Botos, respectivamente. Porém, essas complexas articulações não se fazem sem conflitos, rupturas, descartes e rearranjos, não só no plano expressivo da celebração, mas também no das relações sociais, como apontou Costa (20I I) acerca de uma festa de santo em Belém.

Os festeiros responsáveis pelos ritos do barracão requalificaram positivamente aquilo que, na década de I940, pretendeu banir do Sairé. Músicas, danças e até mesmo o tarubá - ressignificados, retradicionalizados (Travassos, 2004) e ressacralizados - integram atualmente o espaço festivo do barracão que também abriga celebrações ministradas por um padre (Ver Foto 5).

Entretanto, os mesmos festeiros se ressentem da desatenção do poder público, do desinteresse dos jovens pelas expressões culturais antigas, da falta de divulgação dos componentes tradicionais da festa, que, segundo eles, são ofuscados pela divulgação da disputa dos botos e dos shows musicais. Esses, além de serem vistos como profanos, são considerados prejudiciais, porque atrapalham rituais do Sairé como a alvorada - que teria sido abandonada porque, ao amanhecer, ainda há som alto e gente bebendo e fazendo "zoada" na praça. Embora os coordenadores tenham proximidade com a festa do barracão, grande parte dos componentes e espectadores desses grupos parece não se importar com ela. Os representantes dos botos, por sua vez, queixam-se da dificuldade de obtenção de recursos e patrocínios, e da insuficiente infraestrutura da arena, que não permite o aperfeiçoamento e o crescimento dos espetáculos no festival. 


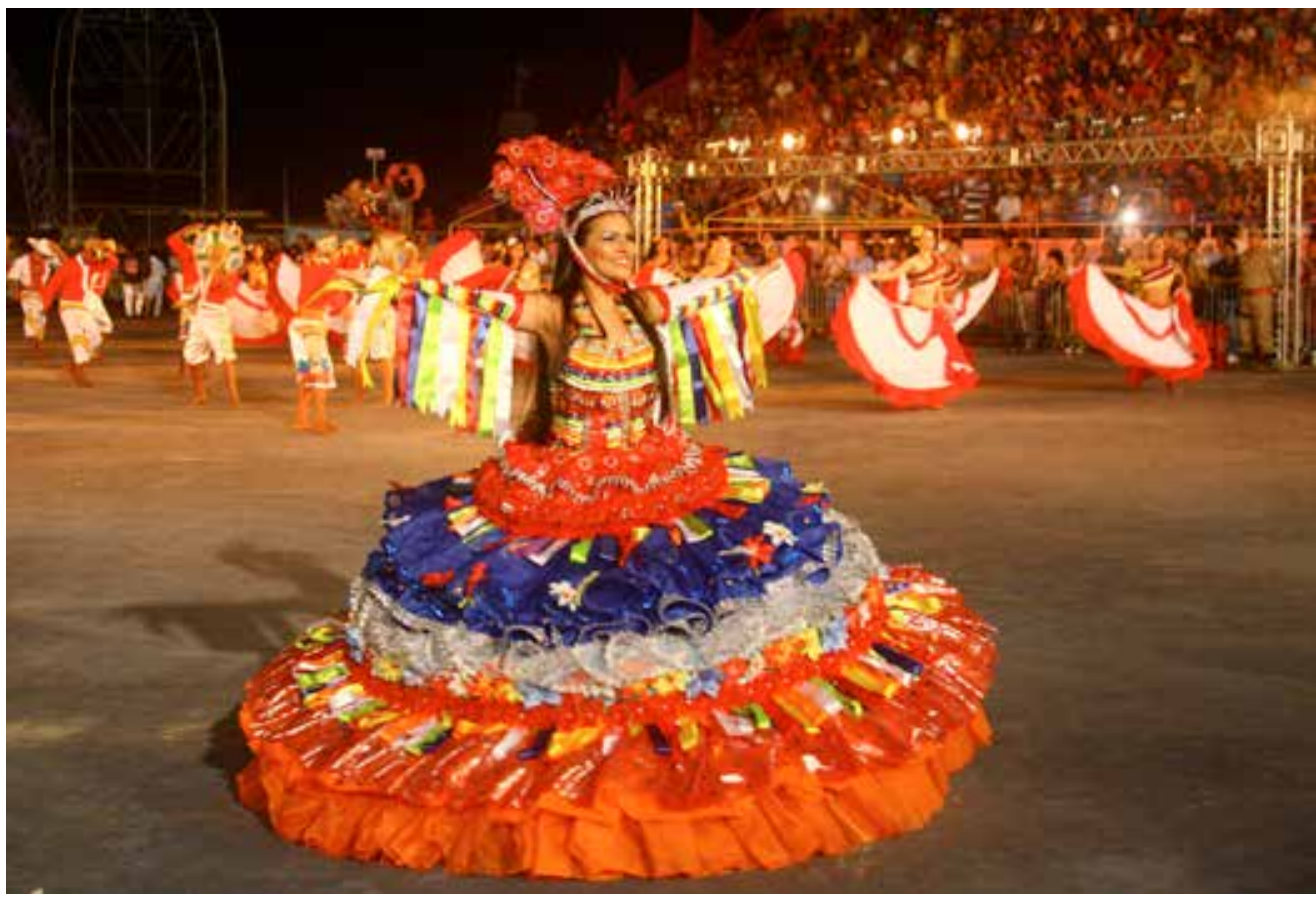

4

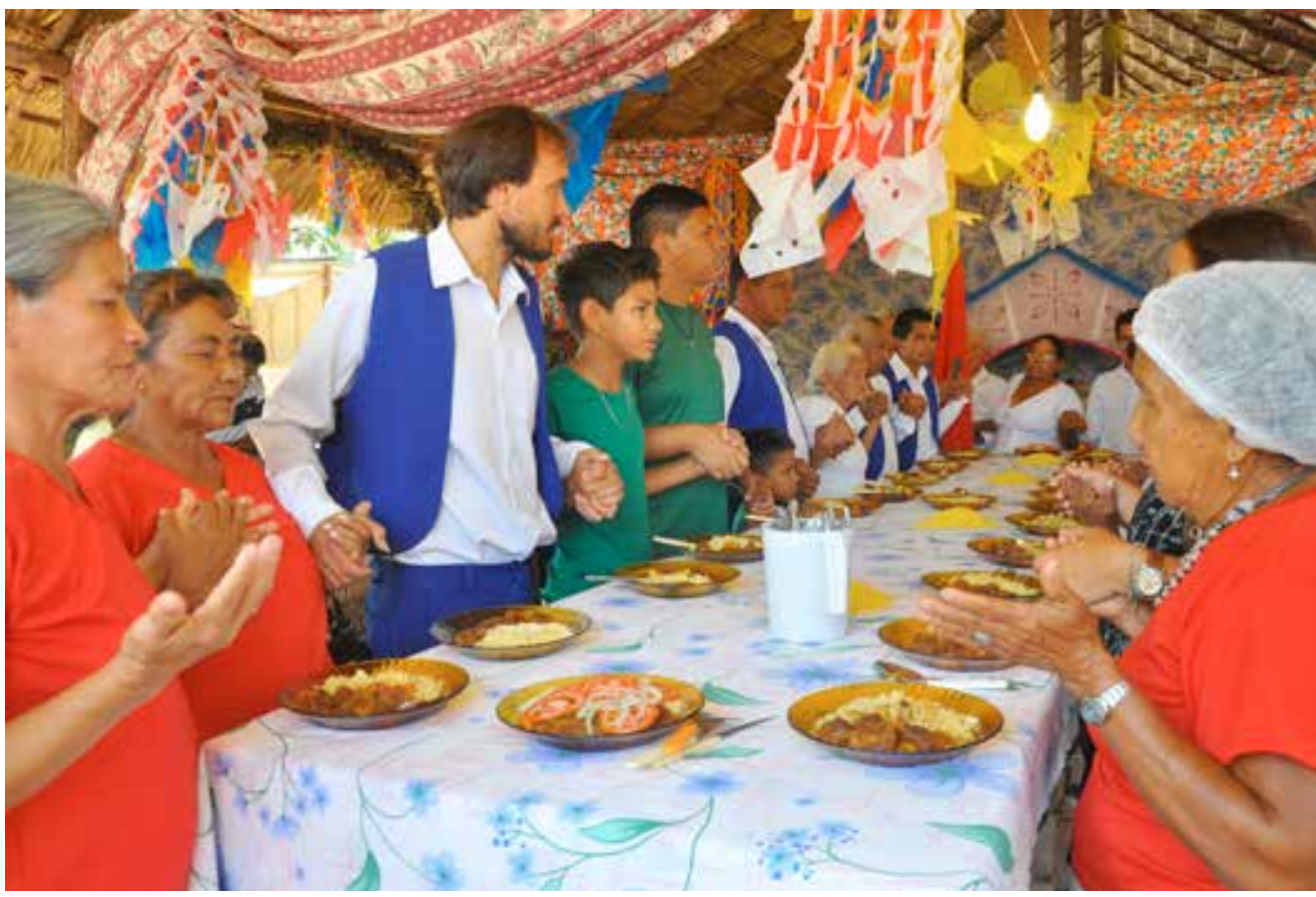


No ensejo do INRC, todos alegam serem emergenciais o registro e a salvaguarda do patrimônio cultural do Sairé, ainda que não haja acordo sobre o que isso significa, exatamente: a festa contemporânea com todos os seus elementos, incluindo os botos, ou apenas as tradições do barracão? Alguns têm defendido, inclusive, que os eventos - os ritos do barracão, que entendem como constitutivos da festa, e o festival - sejam realizados em datas distintas, separando-se aquilo que a década de I990 juntou. Argumentos contrários, baseados na valorização da diversidade que a festa logrou incorporar ao longo dos séculos, acomodando diferenças e não excluindo-as, são apresentados num debate que se mantém latente na comunidade.

No universo ampliado da festa, seu futuro oscila entre tensões e acordos dentro e fora da comunidade. As decisões locais demandam, porém, a apropriação de conceitos de universos estranhos à própria festa. Demandam, ainda, processos complexos de negociação com técnicos, pesquisadores, políticos e empresários. Recaem nesses processos, como bem apontaram Handler (I988), Gonçalves (2007) e Veloso (2007), os riscos de objetificação e fetichização da festa como expressão cultural.

Recebido em 20/0I/20I6 | Aprovado em 22/02/2016

Luciana Gonçalves de Carvalho é doutora em Antropologia Cultural, professora do Instituto de Ciências da Sociedade da Universidade Federal do Oeste do Pará (UFOPA) e do Programa de Pós-Graduação em Sociologia e Antropologia da Universidade

Federal do Pará (UFPA). Atualmente pesquisa comunidades e conhecimentos tradicionais, direitos culturais e conflitos socioambientais na Amazônia. É autora de A graça de contar: narrativas de um Pai Francisco no bumba meu boi do Maranhão (20I I)

e organizadora de Patrimônio cultural na Amazônia: inventários e intervenções (20I2). Coordena o Programa de Extensão Patrimônio Cultural na Amazônia, no âmbito do qual realizou o Inventário de Referências Culturais do Sairé. 


\section{REFERÊNCIAS BIBLIOGRÁFICAS}

Abreu, Martha. (I999). O Império do Divino. Festas religiosas e cultura popular no Rio de Janeiro, I830-I900. Rio de Janeiro/ São Paulo: Nova Fronteira/Fapesp.

Bakhtin, Mikhail. (I993). A cultura popular na Idade Média e no Renascimento. O contexto de François Rabelais. São Paulo/ Brasília: Hucitec/Ed. UNB.

Boyer, Véronique. (2008), Fronteiras da nação: religião, política e ancestralidade. Trabalho apresentado na $26^{\mathrm{a}}$. Reunião Brasileira de Antropologia, Porto Seguro, BA, I a 4 de junho. Braga, Sérgio Ivan Gil. (2007). Festas religiosas e populares na Amazônia: algumas considerações sobre cultura popular. In: Braga, Sérgio Ivan Gil (org.). Cultura popular, patrimônio imaterial e cidades. Manaus: Universidade Federal do Amazonas, p. 55-75.

Braga, Sérgio Ivan Gil. (2002). Os Bois Bumbás de Parintins. Rio de Janeiro: Funarte/EDUA.

Burke, Peter. (I989). Cultura popular na idade moderna. Europa, I 500-I800. São Paulo: Companhia das Letras.

Cândido, Antônio. (s/d). Cururu. Disponível em <www.iel. unicamp.br/revista/index.php/remate/article/downlo$\mathrm{ad} / . . . / 3002>$. Acesso em Io mar. 2013.

Cavalcanti, Maria Laura Viveiros de Castro. (2002). Os sentidos no espetáculo. Revista de Antropologia, 45/I, p. 37-78. Cavalcanti, Maria Laura Viveiros de Castro. (2000). O boi-bumbá de Parintins: breve história e etnografia da festa. Revista História,Ciência e Saúde. (Visões da Amazônia, VI -suplemento especial), p. IoI9-1046.

Chartier, Roger. (I995). Cultura Popular: revisitando um conceito historiográfico. Estudos Históricos, 8/16, p. I79-I92. Costa, Antonio Maurício Dias da. (20I I). Festa de santo na cidade: notas sobre uma pesquisa etnográfica na periferia de Belém, Pará, Brasil. Boletim do Museu Paraense Emílio Goeldi. Ciências Humanas, 6/I, p. 197-216.

Davis, Natalie Zemon. (2008). Culturas do povo: sociedade e cultura no início da França moderna. Rio de Janeiro: Paz e Terra. Dias, João Aluízio Piranha. (20I4). Educação colonial na Amazônia: a pedagogia dos jesuítas e invenção do Sairé. Dis- 
sertação de Mestrado. PPGE/Universidade do Estado do Pará.

Ferreira, Edilberto. (2008). O berço do Çairé. Santarém: Edição do Autor/Valer.

Ferreira, Gicele Brito. (2005). A ressignificação das relações comunitárias e a produção simbólica na mercantilização do Çairé. Dissertação de Mestrado. PPGSS/Universidade Federal do Pará.

Ferretti, Sérgio Figueiredo. (2007). Sincretismo e religião na festa do Divino. ANTHROPOLÓGICAS, II/I8(2), p. IO5I 22 .

Figueira, Cláudia Laurido. (2013). A Festa do Sairé em Alter do Chão (PA): memória e resistência (período I943 a I973). XXVII Simpósio Nacional de História. Disponível em $<$ http://www.snh2or3.anpuh.org/resources/anais>. Acesso em 29 mar. 2016.

Figueiredo, Napoleão \& Silva, Anaíza Vergolino. (I972). Festas de santo e encantados. Belém: Academia Paraense de Letras.

Galvão, Eduardo. (I 955). Santos e visagens: um estudo da vida religiosa de Itá, Baixo Amazonas. 2a. ed. São Paulo/Brasília: Companhia Editora Nacional/INL.

Gonçalves, José Reginaldo Santos. (2007). Antropologia dos objetos: coleções, museus e patrimônios. Rio de Janeiro: Garamond. Gonçalves, José Reginaldo Santos. (2002). A retórica da perda: os discursos do patrimônio cultural no Brasil. Rio de Janeiro: Ed. UFRJ; MinC-Iphan.

Gonçalves, José Reginaldo Santos \& Contins, Marcia. (2008). Entre o Divino e os homens: a arte nas festas do Divino Espírito Santo. Horizontes Antropológicos, I4/29, p. 67-94.

Grandin, Greg. (2009). Fordlândia: ascensão e queda da cidade esquecida de Henry Ford na selva. Rio de Janeiro: Rocco.

Handler, Richard. (I 988). Nationalism and the politics of culture in Quebec. Madison: University of Wisconsin Press.

Hobsbawn, Eric \& Ranger, Terence. (I997). A invenção das tradições. Rio de Janeiro: Paz e Terra.

Leal, João. (2005). Tradição e tradução: festa e etnicidade entre os imigrantes açorianos nos E.U.A. Revista da Faculdade de Ciências Sociais e Humanas, I6, p. 87-108. 
Leal, Mayara Mendes. (20I4). Da missa à eleição: A política do Padre José Maria do Lago na década de I930. Revista Estudos Amazônicos, XI/2, p. 46-78.

Leite, Emanuel Júlio. (200I). Turistificando um caminho da Amazônia. São Paulo: Ícone.

Maués, Raymundo Heraldo. (1995). Padres, pajés, santos e festas: catolicismo popular e controle eclesiástico. Um estudo antropológico numa área do interior da Amazônia. Belém: CEJUP.

Nogueira, Wilson. (2008). Festas amazônicas: boi-bumbá, ciranda e sairé. Manaus: Valer.

Pacheco, Agenor Sarraf. (2010). Encantarias afroindígenas na Amazônia marajoara: narrativas, práticas de cura e (in) tolerâncias religiosas. Horizonte, 8/I7, p. 88-108.

Pereira, Nunes. (I989). O Sairé e o Marabaixo: tradições da Amazônia. Recife: FUNDAJ/ Massangana.

Prado Jr., Caio. (I 999). Formação do Brasil contemporâneo. São Paulo: Brasiliense.

Rêgo, Jackson Fernando. (2003). Enraizamento cultural e o ecoturismo na Amazônia: o caso da vila de Alter do Chão. Tese de Doutorado. CDS/Universidade de Brasília.

Reis, Arthur C. Ferreira. (I979). Santarém: seu desenvolvimento histórico. Rio de Janeiro: Civilização Brasileira.

Revel, Jacques. (I989), A invenção da sociedade. Lisboa: Difel/ Rio de Janeiro: Bertrand.

Rodrigues, Carmem Izabel. (2009). Festividades mestiças na Amazônia. História Revista, I4/ I, p. 235-259.

Rodrigues, João Barbosa. (I 89o). Poranduba amazonense, oukochiyma-uaraporandub, I872-I887. Disponível em <http://biblio.etnolinguistica.org/rodrigues_I89o_poranduba>. Acesso em I 2 ago. 2012.

Tenório, Salete Cardoso. (2012). A Festa do Sairé de Alter do Chão: transformações e permanência no cenário do turismo e da patrimonialização. Monografia de Especialização. PPGDHPP/ Universidade Federal do Oeste do Pará.

Travassos, Elizabeth. (2004). Recriações contemporâneas dos folguedos tradicionais: a performance como modo de conhecimento da cultura popular. In: Teixeira, João Gabriel; Garcia, Marcus Vinicius \& Gusmão, Rita (orgs.). Patri- 
TRADIÇÕES DEVOTAS, LÚDICAS INOVAÇÕES: O SAIRÉ EM MÚLTIPLAS VERSÕES

258

mônio imaterial, performance cultural e (re)tradicionalização. Brasília: ICS-UnB, p. I Io-I I6.

Veloso, Mariza. (2007). O fetiche do patrimônio. In: Abreu, Regina; Chagas, Mário \& Santos, Miriam Sepúlveda (orgs.). Museus, coleções e patrimônios: narrativas polifônicas. Rio de Janeiro: Garamond, p. 229-245.

Wagley, Charles. (1977). Uma comunidade amazônica: estudo do homem nos trópicos. São Paulo: Nacional. 
Palavras-chave

Festas de santo;

Sairé; Invenção da tradição; Alter do Chão;

Pará.

Keywords

Holyfeasts;

Sairé;

Invention of tradition;

Alter do Chão;

Pará (Brasil).
TRADIÇÕES DEVOTAS, LÚDICAS INOVAÇÕES: O SAIRÉ EM MÚLTIPLAS VERSÕES

\section{Resumo}

O texto trata da festa do Sairé de Alter do Chão, uma das mais antigas celebrações conhecidas na Amazônia, com ênfase nos processos de transformação por que ela passou, mesclando tradições devotas e inovações lúdicas e espetaculares. Propõe que as experiências históricas de embates entre festeiros e eclesiásticos, em torno de distintas concepções da festa como ato de devoção, foram apropriadas e positivadas pelos primeiros como estratégia de recriação e ressignificação da celebração, promovendo, por vias singulares, sua continuidade no Baixo Amazonas.

\section{DEVOTIONAL TRADITIONS, PLAYFUL INNOVATIONS:} THE MULTIPLE VERSIONS OF THE SAIRÉ FESTIVAL

\section{Abstract}

This text deals with the Sairé Festival in Alter do Chão, one of the oldest known celebrations in the Amazon, with emphasis on transformation processes by which it passed, merging devout traditions and playful and spectacular innovations. It proposes that the historical experiences of clashes between revelers and church, around different concepts of the party as an act of devotion, were positively appropriate as a strategy for its continuity in the Lower Amazon. 